\title{
Our stories: Women speak out against HIV and AIDS-An interactive communication package for rural low-literate women
}

Vijaya Nidadavolu

Moumita Saha

Vijaya Usha Rani

Follow this and additional works at: https://knowledgecommons.popcouncil.org/departments_sbsr-hiv

Part of the Demography, Population, and Ecology Commons, Family, Life Course, and Society Commons, Gender and Sexuality Commons, International Public Health Commons, and the Medicine and Health Commons How does access to this work benefit you? Let us know!

\section{Recommended Citation}

Nidadavolu, Vijaya, Moumita Saha, and Vijaya Usha Rani. 2007. "Our stories: Women speak out against HIV and AIDS-An interactive communication package for rural low-literate women," Research update. New Delhi: Population Council. 

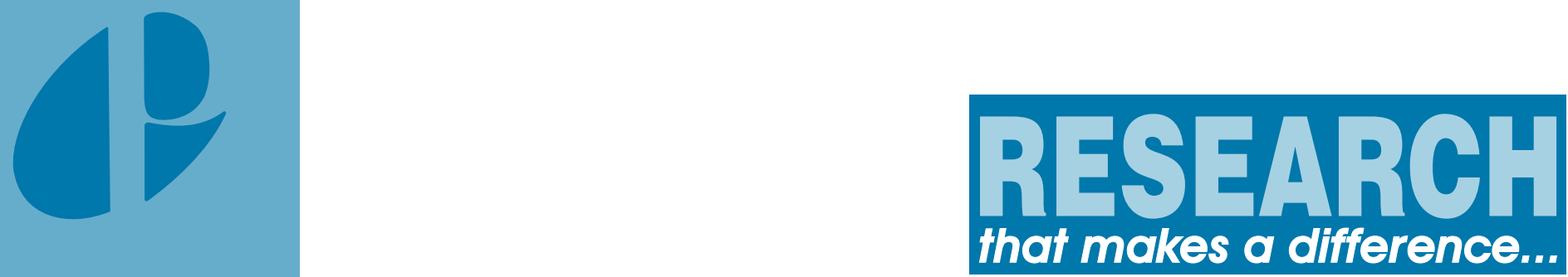

\section{OUR STORIES: WOMEN SPEAK OUT AGAINST HIV AND AIDS An interactive communication package for rural low-literate married women}

\section{Background}

The National AIDS Control Organisation (NACO) estimates that there are over 5.1 million people living with HIV and AIDS in India. Among new infections reported in 2006, $88 \%$ were reported in the reproductive age group (15-49 years). It is now widely acknowledged that the virus is spreading rapidly among women, including married and monogamous women, and adolescent girls. Existing literature shows that women's vulnerability is compounded due to their gendered disadvantage in information access, literacy and decision-making. This disadvantage is particularly acute in the case of married women in rural India.

NACO has indicated in its National AIDS Control Programme Phase II, the need to develop audience-appropriate strategies for communicating HIV-related information. The recommendations include developing culturally appropriate, inter-personal communication tools that reach women, in particular, in media-dark rural pockets. To ensure that rural low- and neo-literate women are equipped with correct information about HIV and AIDS it is necessary to design communication strategies that are evidencebased, participatory and take women's visual perceptions into account.

The Population Council undertook a participatory communications project during 2006 and 2007 to develop visually appropriate communication materials on HIV and AIDS for married rural women, including adolescent girls, in partnership with the Andhra Pradesh Mahila Samatha Society in Andhra Pradesh (AP) and Child In Need Institute in West Bengal (WB).

\section{The process}

The communications project was implemented in two districts in both states. Andhra Pradesh
(Mahboobnagar and Karimnagar), a high prevalence state and West Bengal (South 24 Parganas and Murshidabad), where prevalence rates are on the rise, were chosen to understand how communications strategies might have to be differently implemented depending on prevalence and infection rates and cultural contexts. Further the districts were chosen to understand if proximity to or distance from urban areas led to differential access to information campaigns and therefore greater or lesser awareness about HIV.

In the first phase, partner organisations collated all available communications materials distributed by government and non-government organisations in the two districts. The content of the materials was reviewed to understand if the form, visual imagery, language and overall communication was appropriate for rural lowliterate populations, especially women. In the next phase a consultative communications needs assessment and strategy-building exercise was undertaken with the field-level workers of partner organisations. Thereafter, eight focus group discussions (FGD) were conducted with married women in the four districts to assess their exposure to media in general, comprehension (both language and visuals) of current HIV communications campaigns, message retention, HIV-related information needs and preferred channels for message reception. The FGDs were also used to collect narratives from women about incidents they had heard from/of women affected by HIV. Participants were also shown a set of images on reproductive health drawn by rural women from other parts of India to ascertain if their visual perception was the same as rural women elsewhere. The Council and its partners then developed a communications strategy based on the findings from the FGDs. This strategy was used by a development communications design agency, Vikalpdesign, to develop a draft communication package. Another round of eight FGDs were then held to ascertain if the draft 
materials were indeed effective with the intended audience. After incorporating changes from the pre-testing sessions, the final products were shared with State AIDS Control Societies in the two states to explore possibilities for endorsement, replication and wider distribution. Partner organisations have established a network of organisations working with rural women in each state to ensure wide distribution of the training materials and their optimal use. The following sections describe some of the main findings from the content analysis, the formative FGD phase and the pre-testing FGD phase that guided the development of this communication package.

\section{Communications strategy}

In the initial phase all available materials on HIV were collated by the partner organisations in the chosen four districts of the two states. In AP we found 51 different types of materials and in WB 106 types. These were produced by government and non-government organisations, however most of the materials in AP-almost $75 \%$ of the collected materials - were produced by the AP State AIDS Control Society or the National AIDS Control Organisation. In WB, nearly $50 \%$ of the collected materials were produced either by the WB State AIDS Control Society or the Child In Need Institute. Most of the materials were found to be literacy dependent. In WB, the most popular formats were pamphlets/brochures or handbooks. In $\mathrm{AP}$, posters were the predominant format. Most of the materials were in the regional language. An overall assessment of the visuals revealed that there was a need to produce materials for low-literate women in visual idioms that they understand.

The first round of FGDs with women revealed that women in the districts closer to the urban areas had higher exposure to existing messaging, younger married women had more accurate information and that women perceived HIV to be an urban, migration-related issue. Women's selfperception of risk was low, especially in the context of domestic violence, migration and low negotiation power in intimate relationships. Interestingly, women in WB were more reticent to discuss HIV-related issues compared to women in AP. This could be because of the prevalence rates and the fact that in the latter the issue has been forced into the open due to the greater impact it has had on people's lives. Message retention from existing campaigns were differential in both states, with some women having knowledge about the four routes of transmission to a few women not having heard about HIV at all. Women revealed that their information access was curtailed by lack of education, mobility and no power in decisionmaking. Women across the board expressed the need for visual and colourful materials in a small book format that they could carry easily. They also expressed that someone (either an Auxilliary Nurse Midwife, an Anganwadi worker or an NGO outreach worker) needed to facilitate initial information giving.

\section{Production and distribution}

Based on the findings from the content analysis and the formative FGDs it was decided to make an interactive training manual for NGO trainers to use in groups with women and a take-away booklet that women could carry home from sessions. Based on women's inputs, a limited edition of audio-visual material, in the form of CDs, was also produced. The impact of the CD will be assessed before replicating it for mass distribution. It was also decided to make a single tool for both states as, in general, knowledge regarding HIV was found to be low and misconceptions quite high. So it was felt that one tool would serve the needs of both states. The visual perception of women and the idioms they understood were found common across the two states. Special care has been taken to standardise the content for both states, while maintaining a regional flavour through the names, specific festivals and points for referrals. A training manual titled, "Our stories: Women speak out against HIV" has been produced in Bengali and Telugu and a take-away booklet, titled the same, but with abridged versions of the stories and main HIV messages to be given away to women has also been produced. The booklets contain statespecific voluntary and confidential counselling and testing centre addresses. About 500 copies each of the training manual in Telugu and Bengali have been distributed through NGO networks in the two states and 50,000 copies in each language of the take-away booklets have also been distributed. A follow-up mechanism is being developed with the hope that it will help the coordinating team assess the impact of these materials so that lessons can be drawn for improving the product and explore large-scale replication.

\section{(2) Population Council}

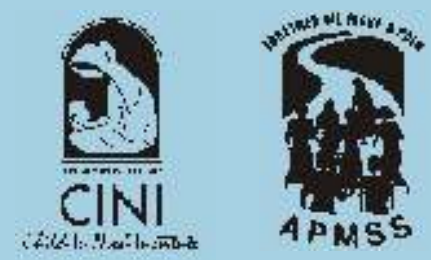

For further information please contact:

Population Council

Zone 5A, Ground Floor

India Habitat Centre, Lodi Road

New Delhi - 110 003, India

Tel: 91-11-2464 2901/02

Fax: 91-11-2464 2903

Email: info-india@popcouncil.org

\section{wWw.popcouncil.org}

\section{Contributors}

Vijaya Nidadavolu (Population Council); Moumita Saha (Child In Need Institute); Vijaya Usha Rani (Andhra Pradesh Mahila Samatha Society)

Donor

Department for International Development 